UDC 336.6: 004.7

JEL Classification: F23; G21; 016

\title{
PROSPECTS AND RISKS OF THE FINTECH INITIATIVES IN A GLOBAL BANKING INDUSTRY \\ ${ }^{\circ} 2020$ SLOBODA L. Y., DEMIANYK O. M.
}

UDC 336.6: 004.7

JEL Classification: F23; G21; 016

\section{Sloboda L. Y., Demianyk O. M. \\ Prospects and Risks of the Fintech Initiatives in a Global Banking Industry}

The aim of the study is to outline the main trends, problems, and risks that should be addressed through cooperation between fintech companies and banks at the current stage of international financial market development. The analysis of the current situation in the financial market shows that innovative technologies play a key role in the development of banking and financial services in the world. The problems of the flexibility of traditional financial institutions do not coincide with the ever-growing needs of clients to receive the highest quality, cheap and fast financial services. Technology-driven companies continue to develop the digital innovation field, which has generated considerable interest in its implementation in banking and finance. The article describes the main reasons for the partnerships between banks and fintech companies, the motives and trends of investing in fintech development, the main stages of preparation for partnership and the area of highest interest for implementation of innovations by international banks. An applied aspect of this article is the analysis of the practical experience and forms of successful cooperation between banks and fintech companies in different countries of the world. The research results highlight the main stages of preparation for international banks' cooperation with fintech companies, as well as the most popular products and services to enhance effective integration between them. Based on the results obtained, measures to strengthen cooperation between banks and fintech companies are justified, which will make the process of satisfying financial services consumers more rapid, simple, accessible, and efficient. The authors identify the major challenges and risks facing the Ukrainian aintech market, including the legal and regulatory environment, slow adoption of innovations by traditional banks, lack of open APIs in the banking sector, limited access to capital and financing for fintechs, etc. A prospect of further research in this area is to substantiate common and distinct approaches to regulating activities of fintech companies in different countries around the world, including capitalization and financial risk management requirements, as well as KYC (Know Your Customer Identification) procedures in customer service. The further development of the fintech industry is significantly transforming the business models of international banks and could lead to the replacement of classic forms of banknotes

Keywords: financial market, banks, fintech, innovation, payments, partnership, integration.

DOI: https://doi.org/10.32983/2222-0712-2020-1-275-282

Fig.: 3. Tabl.: 1. Bibl.: 16 .

Sloboda Larysa Ya. - Candidate of Sciences (Economics), Associate Professor, Associate Professor of the Department of Finance, Banking and Insurance, Lviv Educational-Scientific Institute of the University of Banking (9 T. Shevchenka Ave., Lviv, 79019, Ukraine)

E-mail: larisabaht@gmal.com

ORCID: https://orcid.org/0000-0002-8953-9111

Researcher ID: $h$ ttp://www.researcherid.com/X-1969-2018

Demianyk Oleksandr M. - Manager, Banking Department, LLC Banks for Institutions UA (1 Rudanskiy Str., Lviv, 79000, Ukraine)

E-mail: sdemyanik1@gmail.com

УДК 336.6: 004.7

JEL Classification: F23; G21; 016

Слобода Л. Я., Дем'яник О. М. Перспективи та ризики інціатив Fintech у міжнародному банківництві

Мета цього дослідження полягає в окресленні основних тенденцій, проблем і ризиків, які слід врегулювати шляхом співпраці між компаніями Fintech та банками на сучасному етапі розвитку міжнародного фінансового ринку. Аналіз сучасної ситуації на фінансовому ринку показує, що інноваційні технології відіграють ключову роль у розвитку банківництва та фінансової сфери у світі. Проблеми гнучкості традиційних фінансових установ не співпадають з постійно зростаючими потребами клієнтів в отриманні найвищої якості, дешевих і швидких фінансових послуг. Компанії, що керуються технологіями, продовжують розвивати сферу цифрових інновачій, що спричинило значний інтерес щодо ії імплементації у сфері банківської справи та фінансів. У статті розкрито основні причини партнерських взаємовідносин між банками та Fintech-компаніями, мотиви та тенденції інвестування у сферу розвитку Fintech, основні етапи підготовки до партнерства та сфери найвищої зацікавленості щодо впровадження інновацій з боку міжнародних банків. Прикладним аспектом цієї статті є аналіз практичного досвіду та форм успішної співпраці мін
УДК 336.6: 004.7 JEL Classification: F23; G21; 016

Слобода Л. Я., Демьяник А. Н. Перспективы и риски инициатив Fintech в мировой банковской системе

Цель этого исследования заключается в определении основных тенденций, проблем и рисков, которые следует урегулировать путем сотрудничества между компаниями Fintech и банками на современном этапе развития международного финансового рынка. Анализ современной ситуации на финансовом рынке показывает, что инновационные технологии играют ключевую роль в развитии банковского дела и финансовой сферы в мире. Проблемы гибкости традиционных финансовых учреждений не совпадают с постоянно растущими потребностями клиентов в получении высокого качества, дешевых и быстрых финансовых услуг. Компании, управляемые технологиями, продолжают развивать сферу цифровых инноваций, повлекшие значительный интерес к ее имплементации в сфере банковского дела и финансов. В статье раскрыты основные причины партнерских взаимоотношений между банками и Fintech компаниями, мотивы и тенденции инвестирования в сферу развития Fintech, основные этапы подготовки к партнерству и сферы высокой заинтересованности по внедрению инноваций со стороны международных банков. Приклад- 
банками ma Fintech-компаніями у різних країнах світу. Результати дослідження дають змогу виокремити ключові етапи підготовки до співпраці міжнародних банків з Fintech-компаніями, а також найпопулярніші продукти й послуги для посилення ефективної інтеграції між ними. На основі отриманих результатів обгрунтовано заходи щодо посилення співпраці між банками та Fintech-компаніями, що зробить процес задоволення споживачів фінансових послуг більщ швидким, простим, доступним та ефективним. Авторами визначено основні виклики та ризики, які стоять перед українським ринком Fintech, ceред яких правове та регуляторне середовище, повільне прийняття інновацій традиційними банками, відсутність відкритих АPI в банку, обмежений доступ до капіталу та фінансування для FinTechs mощо. Перспективами подальших наукових досліджень у цьому напрямі $\epsilon$ обгрунтування спільних івідмінних підходів щодо регулювання діяльності Fintech-компаній у різних країнах світу, зокрема, щодо вимог капіталізації та управління фінансовими ризиками, а також здійснення процедур КYC (Know Your Customer Identification) при обслуговуванні клієнтів. Подальший розвиток Fintech-індустрії суттєво трансформує бізнесмоделі міжнародних банків і може привести до заміщення класичних форм банкінгу.

Ключові слова: фінансовий ринок, банки, Fintech, інновації, платежі, партнерство, інтеграція.

Рис.: 3. Табл.: 1. Бібл.: 16.

Слобода Лариса Ярославівна - кандидат економічних наук, доцент, доцент кафедри фінансів, банківської справи та страхування, Львівський навчально-науковий інститут ДВНЗ «Університет банківської справи» (просп. Т. Шевченка, 9, Львів, 79019, Україна)

E-mail: larisabaht@gmal.com

ORCID: https://orcid.org/0000-0002-8953-9111

Researcher ID: http://www.researcherid.com/X-1969-2018

Дем'яник Олександр Миколайович - менеджер, банківський відділ, ТОВ «Бенкс фор Інстітюшинз ЮА» (вул. Руданського, 1, Львів, 79000, україна)

E-mail: sdemyanik1@gmail.com ным аспектом статьи является анализ практического опыта и форм успешного сотрудничества между банками и Fintech-компаниями в разных странах мира. Результаты исследования позволяют выделить ключевые этапы реализации сотрудничества международных банков с Fintech-компаниями, а также наиболее популярные продукты и услуги для усиления эффективной интеграции между ними. На основе полученных результатов обоснованы мероприятия по усилению сотрудничества между банками и Fintech-компаниями, что сделает процесс удовлетворения потребителей финансовых услуг более быстрым, простым, доступным и эффрективным. Авторами определены основные вызовы и риски, которые стоят перед украинским рынком Fintech, среди которых правовое поле и среда компайенса, медленное принятие инноваций традиционными банками, отсутствие открытых API в банке, ограниченный доступ к капиталу и финансированию для FinTechs. Перспективами дальнейших научных исследований в этом направлении является обоснование общих характеристик и различий регулирования деятельности Fintech-компаний в разных странах мира, в частности, относительно требований капитализации и управления финансовыми рисками, а также осуществление процедур КYC (Know Your Customer Identification) при обслужсивании клиентов. Дальнейшее развитие Fintech-индустрии существенно трансформирует бизнес-модели международных банков и может привести к замещению классических форм банкинга.

Ключевые слова: финансовый рынок, банки, Fintech, инновации, платежи, партнерство, интеграция.

Рис.: 3. Табл.: 1. Библ.: 16.

Слобода Лариса Ярославовна - кандидат экономических наук, доцент, доцент кафедры финансов, банковского дела и страхования, Львовский учебно-научный институт ГвУз «Университет банковского дела» (ул. Вячеслава Черновола, 61, Львов, 79019, Украина)

E-mail: larisabaht@gmal.com

ORCID: https://orcid.org/0000-0002-8953-9111

Researcher ID: http://www.researcherid.com/X-1969-2018

Демьяник Александр Николаевич - менеджер, банковский отдел, ООО «Бенкс фор Инститюшинз ЮА» (ул. Руданского, 1, Львов, 79000, украина)

E-mail: sdemyanik1@gmail.com
Introduction. Change is the only constant today. For ages, banks have had no significant competitors at all. Consumers have often needed to pay higher and even hidden fees for banking services. However, during the last decade, the sphere of the financial industry is being shaken and reshaped by digital transformation, customer relationships and experiences changed by new technology. The main goal of Financial Technology is to lead the industry to prosperity.

With recent open banking regulations, banks will have to continue to work beside fintech companies and non-traditional financial services firms in order to deliver their services. Furthermore, today's fintech trends show us that the financial services industry needs to learn how to best integrate technology into their strategy in order to meet the growing requirements of their tech-savvy customers. That is why it is crucial to explore and study the global trends of fintech integration in the banking industry, considering the barriers that occurred and the most significant results.

Literature Review. Possibilities of cooperation between banks and fintechs at the international level are one of the most important and discussed issues in the area of financial innovations and banking among professionals, scientists, lawyers, advisors, and other users of analytical publications. Famous bankers and knowledgeable participants from different authorities, especially the World Bank, International Finance Corporation, Basel Committee on Banking Supervision, Central Banks, Financial Authorities, External Audit Companies, and others, play an important role in the development and implementation of modern practical approaches to the creation of open banking, which is impossible without fintechs.

Schueffel (2016), e.g., states that fintechs are companies that apply technology to improve financial activities. Ernst \& Young's Report (2017) looks at some of the common barriers to effective collaboration - from navigating procurement and vendor risk management to technical implementation - and how banks and fintechs can overcome them. A famous American economist Jim Marous (2018) disclosed the key factors of banks and fintechs collaborations. He explains that moving from a competitive perspective, traditional financial institutions and fintech firms now understand that cooperation may 
be the best path to long-term growth. Tiberius and Rasche (2017) show a huge potential of fintechs by conducting a multiple-case study, which confirms the advantages of new services in several different product segments.

Methods. The methodological basis of the study is a comparative analysis of the modern trends in the global FinTech and banking industry. The authors apply statistical analyses and logical interpretation to estimate analytical trends related to volumes and factors of successful cooperation between financial technology firms and banks.

The purpose of the research. The purpose of the article is to outline the main issues for the integration of innovations in banks globally and to explore the successful partnership examples. Case studies often provide interesting insights and they can motivate a more rigorous analysis of a research problem.

Results. The high cost is one of the reasons preventing consumers from using the required product or service. Some customers, especially those in poor countries, get excluded from the world of financial services. Meanwhile, fintechs are working on reducing the costs by providing services through innovative ways.

New online payment service providers eliminate high bank fees by matching its users' currency demand and supply. This has particularly benefited many customers who use cross-border payments. For example, TransferWise, a money transfer company offering across 750 currency routes, with a customer base of over 1 million. They built a local banking network across the world, which enables money transactions without crossing the borders. The system automatically links the currency flows at the real mid-market exchange rate and pays out from the local account. This approach cuts the traditional banking fees and avoids FX. As a result, transferring GBP1 billion per month globally entails saving consumers GBP1.5 million every day compared to traditional bank transactions. The service is up to 8 times cheaper than the UK's major high street banks [11]. No wonder that this innovative sphere attracts a lot of attention. The fintech industry shows over USD111.8 billion investment in 2018, about five times more than that five years earlier (Fig. 1).

Investments, bln USD

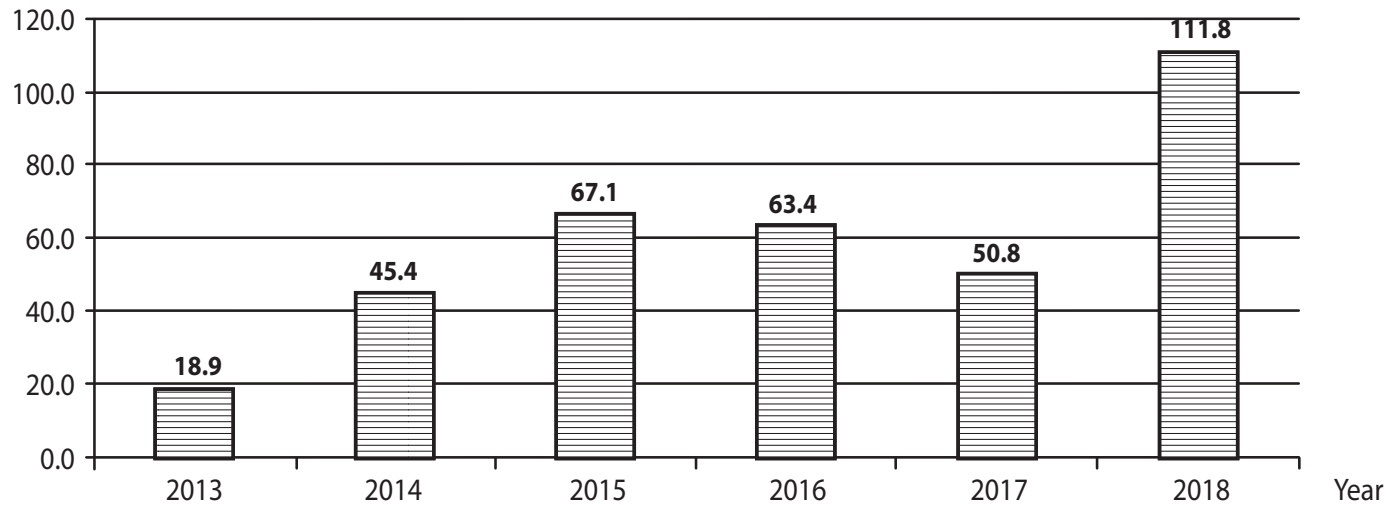

Fig. 1. Total investments in fintechs, 2013-2018

Source: [11]

The global analysis of investment in FinTech shows the following market trends [10]:

- In 2018, global fintech investment hit USD111.8 billion with 2,196 international deals;

- Global investment in fintechs more than doubled, led by three mega 10 billion+ deals;

- Corporate venture capital investment in fintechs topped USD23 billion, more than double 2017 results;

- Global cross-border fintech M\&A activity reached USD53.5 billion in 2018;

- Investment in blockchain and cryptocurrencies stayed at USD4.5 billion.

The growth of the industry has confirmed the common belief that fintechs will disrupt banking. However, cooperation, not a competition, will be the main source of disruption. The most crucial threat to banks comes not from fintechs but from traditional competitors' better cooperation with fintechs [4].

In 2017, the average return on equity (ROE) for the largest 200 global banks was just over $7.1 \%$. If the goal is ROE of $12 \%$, the top 200 global banks should increase their revenues by $15 \%$ and reduce costs by $13.7 \%$. Using fintech solutions will help banks drive down costs, innovate and enhance customer services. For banks to rebuild sustainable ROE, they must create better ecosystems. These will be possible using a partnership approach with fintech firms - to help reduce structural costs, enable enhanced regulatory compliance, and better serve customers.

Financial technology firms tend to recognize the significant costs of customer acquisition in financial services and barriers to international business that banks are well-equipped to overcome. Furthermore, the fintech community is aware of the opportunity to become part of the global banking ecosystem, developing technology that can help transform the entire industry, not just support one bank.

For fintechs, it can be difficult to negotiate the long procurement cycles of big banks. For banks, it's a challenge to successfully implement advanced technology in large organizations based on IT from the 1970s [12]. In the successful partnership process both parties should create their own strategies and follow the market rules (Tbl. 1).

Picking the right fintechs to establish relations with and successfully implement innovations remain challenging for banks that have weak adjustments experience. Fintechs should 
The partnership imperatives for banks and fintechs

\begin{tabular}{|l|l|l|l|}
\hline \multicolumn{2}{|c|}{ Banks } & \multicolumn{2}{c|}{ Fintechs } \\
\hline $\begin{array}{l}\text { Develop fintech innovation } \\
\text { framework }\end{array}$ & $\begin{array}{l}\text { Choose innovation operations } \\
\text { model }\end{array}$ & Articulate value proposition & $\begin{array}{l}\text { Differentiate with regulatory } \\
\text { prowess }\end{array}$ \\
\hline $\begin{array}{l}\text { Assess fintech involvement } \\
\text { strategies }\end{array}$ & $\begin{array}{l}\text { Manage staff and system } \\
\text { change }\end{array}$ & $\begin{array}{l}\text { Be prepared and well- } \\
\text { networked }\end{array}$ & $\begin{array}{l}\text { Build a robust business } \\
\text { opportunity }\end{array}$ \\
\hline
\end{tabular}

Source: [14]

better present the clear benefits of their technology and show the results in practice. The following steps are recommended for effective cooperation with banks:

- ensure leadership buy-in;

- establish explicit business objectives;

- align expectations at the start;

- gain access to incumbent firms' infrastructure;

- ensure cultural compatibility;

- define ownership of the intellectual property;

- develop and monitor indicators;

- seek timely dialogue with stakeholders;

- monitor continuously;

- develop contingency plans to protect against partnership failure [12].
A partnership approach enables a range of banks to jointly develop new technology ecosystems that they can adopt in the future. Large banks in the Asia-Pacific region are more focused on developing products in-house than those in other regions, particularly in the digital payments space to serve the underbanked customer segment. North American banks prefer investments over product development, and a number of major US banks have invested in fintech start-ups. European banks have typically taken a balanced approach and may be more willing to make mergers and acquisitions part of their fintech strategy. Generally, only one-quarter of the 45 global banks are actively engaging with fintechs by collaboration, developing their own fintech products, investing in innovative firms or buying them.

Banks' preferences, $\%$

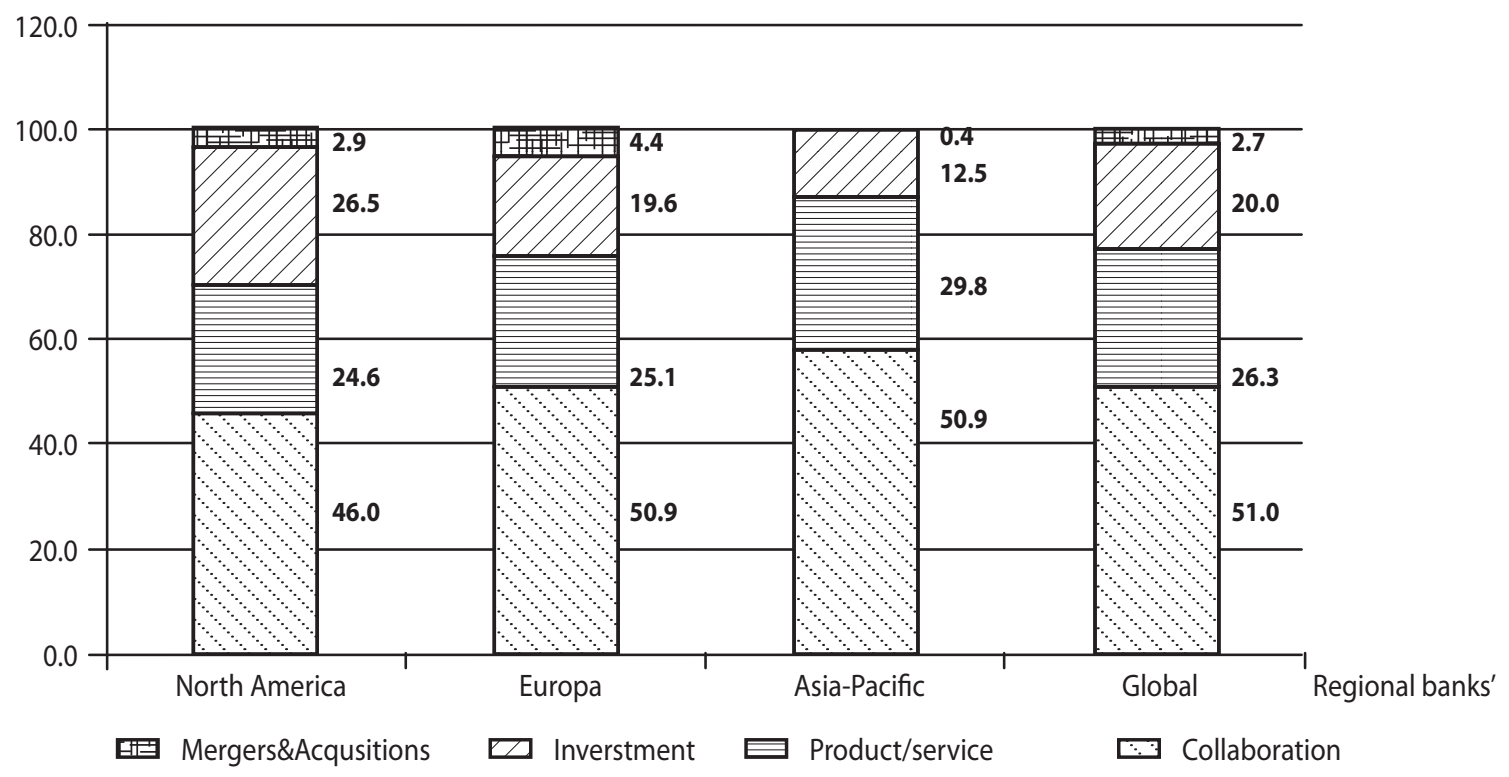

Fig. 2. Regional banks' preferences towards cooperation with fintechs

Source: $[14]$

Fintech firms should be clear about their pricing strategy, which needs to reflect the value for both parties. Another common concern is the protection of intellectual property. In many instances, ideas have been shared in confidence with banks, only for their in-house IT functions to build something comparable. It is essential for fintech firms to find a balance between protecting and sharing. Clearly, for a value proposition to be compelling, the core concept needs to be explained and justified [4].
Partnerships can be equally beneficial for both sides. There is an opportunity for banks to increase revenue and provide more services without necessarily taking on additional risks or involving new staff while providing a new level of services. At the same time, fintechs can obtain a key to a new customer base and the opportunity to leverage extensive financial services while navigating the regulatory environment.

Usually, banks enable new fintech products by providing network, know-how, their own products. They enable the fin- 
tech industry's entry by giving regulatory infrastructure, products and funds. Banks also increase fintech's profits by providing Clients, Network, Funds, and Reputation.

Significant benefits for the banks when it comes to partnerships are the following [6]:

- willingness to cooperate with fintech companies to develop a solid structure of improvements towards innovation;
- continuously engage their regular customer base with innovative, digital options;

- improvement of customer satisfaction through the agility and new insights from fintechs.

Banks see the benefits of their collaboration with fintechs in the spheres mentioned in Figure 3.

Banks are constantly evaluating improvements of services and offerings for their customer base. Fintech firms are

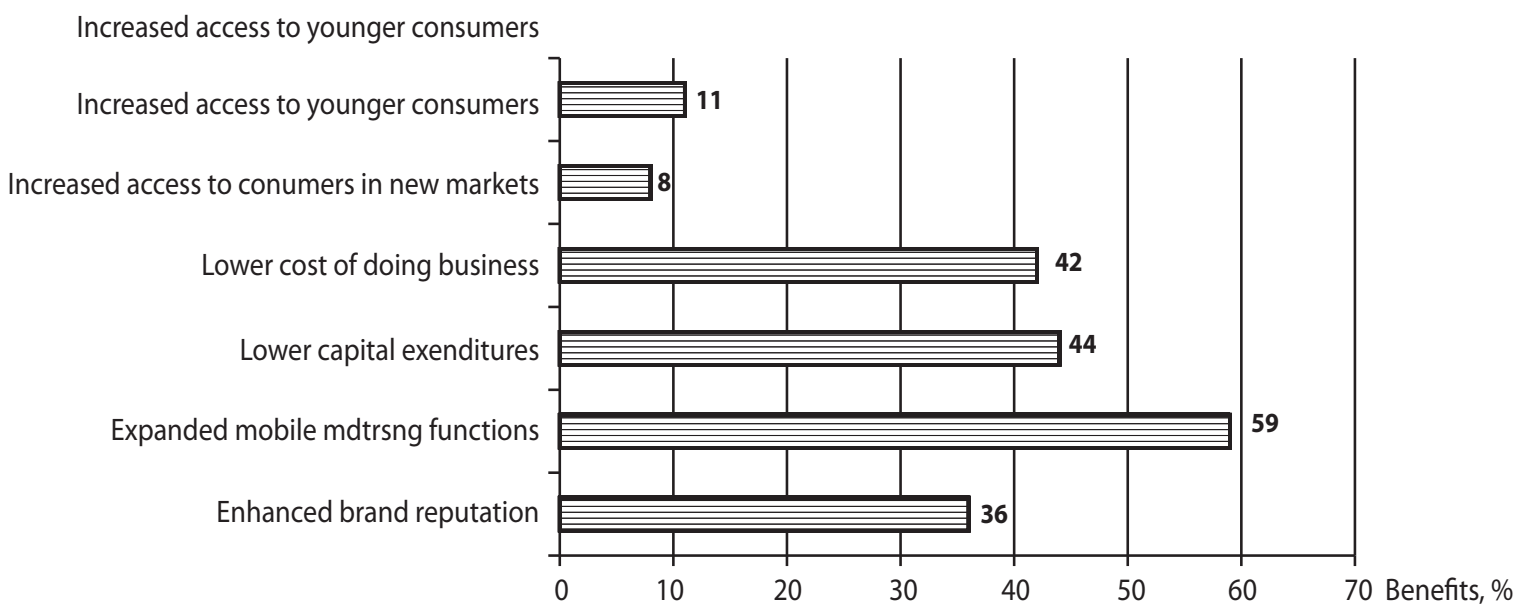

Fig. 3. Benefits banks identify from fintech partnerships

Source: [6]

trying to establish themselves in the long-term run as strong providers of financial services through ongoing, quality usage and customer activation. Generally, both banks and fintech companies are focused on increasing the market share that can clearly come from a successful partnership.

The main improvements in the application of digital technology have occurred so far in lending, payment systems, financial advising, and insurance. In all those areas of business, fintech has the potential to reduce the cost of intermediation and broaden access to financial services increasing financial inclusion. One of the most important reasons for this role lies in the possibility to help overcome information asymmetries, which are at the root of the banking industry. At the same time, financial technology firms have no legacy and old technologies to deal with. This leads them to have a larger innovating capacity than traditional entities.

Banks still dominate the market for transaction services, but payment innovations usually come from non-banks such as PayPal or TransferWise. Mobile-based payment schemes have a great impact in countries where the share of people owning a current account at a bank is small. For instance, countries in Africa where only one in four people have a bank account but, on the contrary, many of them have access to a mobile phone, are becoming testing fields for new payment systems as well as for loans for consumers with little credit history.

Traditional payment systems may also be disrupted by digital currencies. In those currency infrastructures or cryptocurrencies, encryption techniques regulate the generation of currency units using blockchain technology.

Additionally, according to the report by Accenture, blockchain itself can help investment banks cut costs by more than $30 \%$ across the middle and back office, translating into savings from USD8 to USD12 billion annually. Blockchainbased systems remove the overhead costs related to confirming authenticity. Using a distributed ledger system, confirmation is effectively performed simultaneously by everyone on the network. This reduces the need for intermediaries - stock exchange, money transfer services, payment networks, etc. [1].

Robo-advisors, computer programs that generate investment advice according to information they have about customers, and using machine learning tools, are a cheap alternative to human wealth advisors. Furthermore, if programmed properly, robo-advisors may avoid some of the usual conflicts of interest that plague the sector [7].

Software-as-a-Service is a common approach where fintechs license or sell their underlying technology to banks and other financial institutions. Typically, this would be a white label offering where the bank puts its branding on the product to offer an end-to-end solution. Fintech startups, on the other hand, get access to low-cost funding through a trusted partnership while knowing that the regulatory requirements will be taken care off through the bank's infrastructure.

Referral is an especially interesting approach - as it would almost seem counterintuitive - where banks refer clients to relevant fintechs to plug the gaps in their service offerings. But it is also a process that can help the billions of unbanked and underserved individuals globally to get access to better financial service offerings. It is particularly common in the lending sector where fintechs are typically able to offer quicker customer onboarding, faster processing \& approval times, cheaper loans, and more alternative methods of funding \& lines of credit. For banks, there are a number of benefits to the referral 
approach. They improve the customer experience by plugging product gaps with outsourced fintech services, which will help to retain the customer relationship. Referral fees can also be an additional source of revenue.

The more traditional approach would be for banks to purchase the rights to the technology or buy-out the company as a whole. But, contrary to popular belief, this is not very common, and the acquisition activity has only picked up recently.

According to the survey by London law firm Simmons \& Simmons, $31 \%$ of banks and asset managers were expected to fully acquire a fintech startup in 2018. Examples of top banks acquiring startups include BBVA (Madiva, OpenPay, Simple), BNP Paribas (Gambit, Compte Nickel), Goldman Sachs (Final, Finance It, Honest Dollar), and JP Morgan Chase (WePay, MCX) [13].

The practice research shows a lot of successful examples of the collaborations between banks and fintechs. Some of them are listed below.

1. Commerzbank wanted to launch a mobile based app for its banking services. Unfortunately, EU laws require that bank customers verify their identity to the bank in person, which would mean that signups outside a bank branch are impossible. However, ID now came into the picture and gave them a solution that allows them to verify their customers' identities via video on their smartphone or computer. It results in a $50 \%$ increase in conversion for customers sought and downloaded the app and became customers.

2. FidorBank built an online bank account that includes a wide range of financial products including a realtime, easy to use and low cost ePayment system. What was only missing is an eWallet that allows Fidor Bank customers to buy currency, make payments and view balances in multiple European, North American, and Australian currencies. CurrencyCloud offered them a payment engine that they could include into their services without any investment in additional infrastructure. Thus, a huge reduction in forex costs for FidorBank customers, which led to growth in customer base from 200,000 to 315,000 customers (157.5\%).

3. Bankia, a Spanish bank that manages 33,000 SMEs sending and receiving invoices. Managing this process has created huge costs for the bank, and causes suppliers to be delayed in payments. Eurobits offered them an invoicing system that allows creating the supplier portals to operate with the bank. Bankia moved the invoicing services of 33,000 SMEs to an electronic system, and almost all its invoices are now electronic, resulting in the reduction of cost of sending/receiving an invoice to EUR2.50 and payment period to an average of 10 days.

4. A mobile bank, N26, offers a free current account and a debit Mastercard to its customers. Anyone in the Eurozone can use this card from any country, and can sign up in under 10 minutes with a valid ID. At the beginning, there was a need to use regular banks for making foreign payments at a high cost. However, they signed agreement with Transferwise, which significantly lower the cost of making cash withdrawals in a foreign country that did not use EUR. N26 started from 100,000 customers before its Transferwise partnership and went to 500,000 customers (500 \%) in the 2 years since, by removing one of the biggest barriers to their internationalization: forex costs [14].

5. JPMorgan Chase has signed an agreement with Plaid, a leading data aggregator, marking an important milestone in efforts to protect customers' financial data. This will assist customers in using popular financial apps to make decisions with their money while giving them control over how their data is used and accessed. Secure API enables information to be shared securely for 2.3 million Chase consumers and small business customers [9].

6. Another mobile bank, Tandem Bank, announced a new automatic savings service that will be powered by the global payment system of Stripe. Tandem Bank said the new option allows customers to set up rules that automatically move money from their current accounts with other providers to a savings account with Tandem. Users are creating individual sets of rules, such as rounding any payment up to the nearest pound, to make saving weekly [15].

7. Diamond Trust Bank (DTB) is partnering with Kopo Kopo in Kenya and Uganda to serve retail merchants. Kopo Kopo equips retail merchants in East Africa to accept digital payments and offers them small loans. In Uganda, Kopo Kopo and Diamond Trust Bank teamed to create PayEasy, a mobile wallet connected to a DTB account. The partnership aids DTB's focus on reaching SMEs, Kopo Kopo's primary customer base. DTB provides an access to full-functioning bank accounts for Kopo Kopo merchants. Kopo Kopo provides the payments technology and platform as well as access to a vast network of retail merchants who are already using its service. Mastercard is partnering with Grindrod Bank and Net1 to reach unbanked population segments in South Africa. The partnership is part of a larger effort by the South African government to provide bank accounts and debit cards to 17 million social grant recipients and thereby digitize social grant payments. Grindrod Bank provides the banking license for the operation and the bank accounts for new customers. Mastercard provides the network and access to POS and ATMs. Net1 provides the biometric technology and a customer onboarding process.

8. ICICI Bank is cooperating with Stellar to build a blockchain payments system. Stellar provides ICICI Bank with blockchain infrastructure designed to oversee the movement of money. Indian and foreign customers of ICICI Bank can transfer money through a free mobile wallet over Stellar's platform. These transfers are made in real fiat currency, but internally they are documented in cryptocurrency. While the transfers are recorded on Stellar's ledger in a cryptocurrency called "lumens", ICICI Bank holds the value for these transactions in Indian rupees in a pooled account.

9. Santander Bank is partnering with PayKey to build 
a peer-to-peer payments platform integrated into messaging applications such as WhatsApp and Facebook Messenger. The platform allows Santander's customers to send funds from their accounts to friends or family by pressing a custom key on the phone's keyboard, entering an amount, and verifying the transaction. PayKey developed the platform, including the integration of a key into customers' keyboards $[5$, c. 28$]$.

Some banks consider that the best form of defense is attacks. They are launching their own fintechs to expand their market share. For example, Goldman Sachs launched its online bank offering competitive rates on savings accounts and liquid CDs, named Marcus. The company has accumulated more than USD26 billion in deposits and lent USD3 billion to customers, generating over USD1 billion of new revenue for Goldman Sachs. Marcus allows its customers to benefit from one of the highest savings account interest rates available. ING launched its mobile one-stop money platform - Yolt, which aimed to help people keep track of their finances. The company was established in the UK in June 2017 and has quickly sped to 500,000 registered users in less than 18 months [2]. Royal Bank of Scotland (RBS) has announced the launch of a new digital bank, named Bo, which is aimed at customers with tight budgets who want to take greater control of their spending. It also offers a digital alternative to the slew of challenger banks presenting genuine competition to their traditional rivals [8].

The analysis shows that banks have taken proactive efforts to counter challenges created by fintech. They have created internal digital teams and are exploring the possibilities in startups, partnerships, and funding. Apart from such efforts, banks also need to focus on their IT operating model. Banks should adopt a fintech strategy to create a real advantage. They should be bound to follow build fast or fail fast approach which has been one of the important factors for fintech success recently. Consumers are the ones who are real and clear winners. In view of this, one can easily conclude that the collaboration between banks and fintech will make a process faster, better, more simple, efficient and above all Customer-centric [3].

In case of Ukraine, fintech is beginning to take off with more than 60 companies at different stages of maturity. Experience shows, that PrivatBank (prior to its nationalization) was arguably the largest fintech example in the country, offering technological services that were ahead of not only the local Ukrainian market but also the European one. Fintech started to draw the attention of the financial sector players of Ukraine only in 2017 after a series of fintech related forums and events. It was expected that more focused efforts to support the development of this important sector would take place till 2020 [16].

Fintech development is also being actively supported through various initiatives undertaken by the National Bank of Ukraine. It approved the Comprehensive Program of the Ukrainian Financial Sector Development (Resolution No. 391 dated 18 June 2017), which includes a number of initiatives, such as cashless 2020 Strategy, exchange of documents in electronic format using electronic signatures; cancellation of stamps, seals and paper copies; storage of documents in electronic format; remote identification of a person; possibility to order fi- nancial services online; electronic certification of scanned copies and signing of cash documents; possibility to use the Bank ID system for remote identification; protection of the rights of financial services users; new rules to facilitate the licensing of payment service providers. It is important to note that the top management of Ukrainian fintechs consists mainly of ex-bankers $(70 \%)$ with experience at large commercial banks, e.g., PrivatBank, FUIB, Raiffeisen Bank Aval, Universal and Alfa-Bank. About $23 \%$ of managers are business environment managers, and $7 \%$ are from the IT sector. Over $37 \%$ of the fintech providers are engaged in the B2B market segment and target SMEs. Several of the fintech providers have partner relationships with banks and international payment system providers. These include, white labeled P2P card service transactions, supporting co-branded payment cards and payment services. The primary partners include PUMB, Oschadbank, Alfa Bank, Raiffeisen Bank Aval, Tascombank, and international payment service providers.

Currently, the main challenges and risks facing the Ukrainian fintech market include the legal and regulatory environment; slow pace of adoption of innovations by traditional banks; lack of open APIs within the banking sector; limited access to capital and financing for fintechs. Appropriate adjustment of these risks can build and promote a resilient and thriving financial system, and engage many users, suppliers, innovators, peers to help shape and deliver a resilient and innovative payment ecosystem in our country.

Despite the high probability of risks of digital technologies, the potential of their use is much higher, so public authorities should develop national digital transformation strategies, improve the institutional structure of fintech, monitor the most advanced global financial technologies, adapt to international regulatory practices and oversee regulations. It is also necessary to increase consumer awareness and financial literacy.

Conclusion. This paper analyzes the key reasons for banks and fintechs to cooperate based on the analytical results of case-studies and major trends in the market. The study defines the main stages of pre-cooperation preparations for fintech and the most popular products for integration. Banks need to push ahead with further digitalization and adopt more fintech products as part of this drive. Moreover, the investment trends in fintech show that the revolution begins and banks will be forced to cooperate with financial technology firms.

The best advantage of fintech, as a whole, is the speed at which it can develop. While it can take years for an established and regulated financial company to launch some sort of a new service, fintech companies can appear out of nowhere and start taking their share of the market. Besides this, the study shows that preferences regarding the type of cooperation differ from region to region. So, it is very important to explore more deeply such differences.

The crucial point is benefits that banks identify from fintech partnerships. It shows that fintechs will be strongly focused on a few major areas (mobile banking, cost-saving programs). Banks begin to plug the gap between recognizing the importance of technology and actually incorporating it into their business models. At the same time, those banks that do already have a system in place to support fintech adoption - or have already set out on the path to instating one - are in a good 
position with regards to what will be an increasingly vital and defining aspect of the future of the industry. The traditional barrier between the developed world and emerging markets is shrinking fast thanks to the rapid digitization and development of the fintech industry. As a result, we are heading to a completely digitized, transparent and decentralized global financial system much sooner than it was previously thought.

\section{LITERATURE}

1. Accenture. Banking on Blockchain: A Value Analysis for Investment Banks. 2017. URL: https://www.accenture.com/_ acnmedia/accenture/conversion-assets/dotcom/documents/ global/pdf/consulting/accenture-banking-on-blockchain. pdf\#zoom $=50$

2. Arnold M. Five ways banks are responding to the fintech threat // Financial Times. 2018. URL: https://www.ft.com/content/ d0ab6b84-c183-11e8-84cd-9e601db069b8

3. Chaudhary R. Banks and Fintechs // Finextra. 2018. URL: https://www.finextra.com/blogposting/15435/banks-and-fintech

4. Unleashing the potential of FinTech in banking // EYGM Limited. 2017. URL: https://www.ey.com/Publication/vwLUAssets/ ey-unleashing-the-potential-of-fin-tech-in-banking/\$File/eyunleashing-the-potential-of-fin-tech-in-banking.pdf

5. Ferenzy D., McGrath A., Kelly S. How financial institutions and fintechs are partnering for inclusion: lessons from the frontlines // MetLife foundation. 2017. URL: https://content. centerforfinancialinclusion.org/wp-content/uploads/ sites/2/2018/08/IIF-CFI_FI-Fintech_Partnerships_Final.pdf

6. How fintech partnerships with banks shape the future of finance // Fintechtris. 2019. URL: https://www.fintechtris.com/ blog/2019/6/20/how-fintech-partnerships-with-banks-shape-thefuture-of-finance

7. Fintech and Banking. Friends or Foes // IESE Business School. 2017. URL: https://blog.iese.edu/xvives/files/2018/02/ EE_2.2017.pdf

8. Johnson S. How RBS-backed digital bank Bó is trying to tackle consumer debt crisis // NS Banking. 2019. URL: https://www. nsbanking.com/analysis/digital-bank-bo-rbs/

9. Plaid Signs Data Agreement with JPMorgan Chase // JP Morgan Chase \& Co, 2018. URL: https://media.chase.com/news/ plaid-signs-data-agreement-with-jpmc

10. The pulse of Fintech 2018. Biannual global analysis of investment in fintech // KPMG Fintech, 2019. URL: https://assets. $\mathrm{kpmg} /$ content/dam/kpmg/xx/pdf/2019/02/the-pulse-of-fintech2018.pdf

11. Value of Fintech // KPMG International Cooperative, 2017. URL: https://assets.kpmg/content/dam/kpmg/uk/pdf/2017/10/ value-of-fintech.pdf

12. Maros J. Banking + Fintech Collaboration: More Important Than Ever. 2018. URL: https://thefinancialbrand. com/71050/banking-fintech-collaboration-bigtech-trends/

13. Mathews A. Mutually Beneficial Bank-FinTech Collaboration Models // Medici. 2018. URL: https://gomedici.com/ mutually-beneficial-bank-fintech-collaboration-models

14. Prateek S. 7 successful bank fintech partnerships and what they have in common. 2018. URL: https://www.linkedin. com/pulse/7-successful-bank-fintech-partnerships-what-havecommon-sanjay

15. Tandem partners with Stripe on new auto save feature // PYMNTS. 2018. URL: https://www.pymnts.com/news/digitalbanking/2018/tandem-stripe-auto-savings-digital-banking/
16. Fintech in Ukraine: trends, market overview and catalogue. Report. 2018. 77 p. // USAID. URL: https://data.unit.city/ fintech/fgt34ko67mok/fintech_in_Ukraine_2018_en.pdf

\section{REFERENCES}

Accenture. Banking on Blockchain: A Value Analysis for Investment Banks". 2017. https://www.accenture.com/_acnmedia/ accenture/conversion-assets/dotcom/documents/global/pdf/consulting/accenture-banking-on-blockchain.pdf\#zoom $=50$

Arnold, M. "Five ways banks are responding to the fintech threat". Financial Times. 2018. https://www.ft.com/content/ d0ab6b84-c183-11e8-84cd-9e601db069b8

Chaudhary, R. "Banks and Fintechs". Finextra. 2018. https:// www.finextra.com/blogposting/15435/banks-and-fintech

"Fintech and Banking. Friends or Foes". IESE Business School, 2017. https://blog.iese.edu/xvives/files/2018/02/EE_2.2017.pdf

"Fintech in Ukraine: trends, market overview and catalogue. Report. 2018". USAID. https://data.unit.city/fintech/fgt34ko67mok/ fintech_in_Ukraine_2018_en.pdf

Ferenzy, D., McGrath, A., and Kelly, S. "How financial institutions and fintechs are partnering for inclusion: lessons from the frontlines". MetLife foundation. 2017. https://content.centerforfinancialinclusion.org/wp-content/uploads/sites/2/2018/08/IIFCFI_FI-Fintech_Partnerships_Final.pdf

"How fintech partnerships with banks shape the future of finance". Fintechtris. 2019. https://www.fintechtris.com/ blog/2019/6/20/how-fintech-partnerships-with-banks-shape-thefuture-of-finance

Johnson, S. "How RBS-backed digital bank Bo is trying to tackle consumer debt crisis". NS Banking. 2019. https://www.nsbanking.com/analysis/digital-bank-bo-rbs/

Maros, J. "Banking + Fintech Collaboration: More Important Than Ever". 2018. https://thefinancialbrand.com/71050/bankingfintech-collaboration-bigtech-trends/

Mathews, A. "Mutually Beneficial Bank-FinTech Collaboration Models". Medici. 2018. https://gomedici.com/mutually-beneficial-bank-fintech-collaboration-models

"Plaid Signs Data Agreement with JPMorgan Chase". JP Morgan Chase \& Co, 2018. https://media.chase.com/news/plaid-signsdata-agreement-with-jpmc

Prateek, S."7 successful bank fintech partnerships and what they have in common". 2018. https://www.linkedin.com/pulse/7successful-bank-fintech-partnerships-what-have-common-sanjay

"Tandem partners with Stripe on new auto save feature". PYMNTS. 2018. https://www.pymnts.com/news/digitalbanking/2018/tandem-stripe-auto-savings-digital-banking/

"The pulse of Fintech 2018. Biannual global analysis of investment in fintech". KPMG Fintech, 2019. https://assets.kpmg/ content/dam/kpmg/xx/pdf/2019/02/the-pulse-of-fintech-2018. pdf

"Unleashing the potential of FinTech in banking". EYGM Limited, 2017. https://www.ey.com/Publication/vwLUAssets/eyunleashing-the-potential-of-fin-tech-in-banking/\$File/ey-unleashing-the-potential-of-fin-tech-in-banking.pdf

"Value of Fintech". KPMG International Cooperative, 2017. https://assets.kpmg/content/dam/kpmg/uk/pdf/2017/10/valueof-fintech.pdf

Стаття надійшла до редакції 11.02 .2020 p. 